ISSN (print): 1698-6180. ISSN (online): 1886-7995

www.ucm.es/info/estratig/journal.htm

Journal of Iberian Geology 37 (2) 2011: 161-172

doi: 10.5209/rev_JIGE.2011.v37.n2.5

\title{
New rodent faunas from Middle Miocene and Mio- Pliocene in the Cabriel Basin (Valencia, Spain)
}

\author{
Nuevas faunas de roedores del Mioceno medio y del Mio-Plioceno en la cuenca \\ del Cabriel (Valencia, España)
}

\author{
F.J. Ruiz-Sánchez ${ }^{1 *}$, C. Santisteban ${ }^{1}$, V.D. Crespo-Roures ${ }^{1}$, M. Freudenthal2,3 \\ ${ }^{1}$ Departament de Geologia, Universitat de València, 46100 Burjassot, Spain \\ francisco.ruiz@uv.es; carlos.santisteban@uv.es; vidacres@alumni.uv.es. \\ ${ }^{2}$ Departamento de Estratigrafía y Paleontología, Universidad de Granada, 18071 Granada, Spain \\ mfreuden@ugr.es \\ ${ }^{3}$ Netherlands Centre for Biodiversity, Naturalis, P.O. Box 9517, NL-2300 RA Leiden, The Netherlands \\ *corresponding author
}

Received: 20/06/11 / Accepted: 19/10/11

Abstract

Five new localities with micromammal remains have been located in the Cabriel Basin. These localities are situated in the eastern area of the Cabriel Basin, in the Juan Vich ravine, where the oldest deposits of this basin crop out. The localities JV2, JV3 and JV6 are of Middle Miocene age, JVTLI1 of Middle Miocene or Late Miocene age and JVTS1 of Late Miocene or Early Pliocene age. The beginning of the sedimentary history of the basin was attributed to Late Turolian (Late Miocene). The new sedimentary record from the Juan Vich ravine and the mammalian findings extend the stratigraphic and paleontological knowledge of the Basin.

Keywords: Rodentia, Aragonian, Turolian-Ruscinian, Miocene-Pliocene, Cabriel Basin, Spain

\section{Resumen}

Cinco nuevas localidades con restos de micromamíferos han sido localizadas en la cuenca del Cabriel. Estas localidades se sitúan en el sector este, en el conocido como barranco de Juan Vich, donde afloran los depósitos más antiguos de esta cuenca. Las localidades JV2, JV3 et JV6 son del Mioceno medio, del Mioceno medio o superior JVTLI1 y del Mioceno superior o Plioceno inferior JVTS1. El inicio de la sedimentación en esta cuenca se había datado en el Turoliense. El registro sedimentario del barranco de Juan Vich y la fauna de mamíferos hallada en él, amplían el conocimiento estratigráfico y paleontológico de esta cuenca.

Palabras clave: Rodentia, Aragoniense, Turoliense-Rusciniense, Mioceno-Plioceno, cuenca del Cabriel, España 


\section{Introduction}

The oldest sediments of the Cabriel basin crop out along the Juan Vich ravine (Fig. 1). The depositional environment of these deposits is continental. Two important localities of large mammals of Late Turolian age, Venta del Moro (Montoya et al., 2006) and La Portera (Lacomba et al., 1986) are known in the Cabriel valley area. Both localities are situated below the limestone Unit that forms the uppermost deposits from this basin. They contain a varied fossil assemblage, 39 species of mammals in Venta del Moro, many of which are immigrants of Asian or African origin (Montoya et al., 2006).

The more extensive area of the Jucar-Cabriel valleys has yielded a rich set of fossil micromammal localities (Aguirre et al., 1973; Alberdi et al., 1982; Alberdi et al., 1997; Benavent et al., 2008; Freudenthal et al., 1998; Lacomba et al., 1986; López-Martínez, 1989; Mansino et al., 2009; Martín-Suárez et al., 1998; Martín-Suárez et al., 2000; Mein et al., 1978; Mein and Martín-Suárez, 1993; Montoya et al., 2006; Morales, 1984; Opdyke et al., 1990; Opdyke et al., 1997; Robles et al., 1974; RuizSánchez et al., 1994). The age of these faunal assemblages covers a time span from Late Aragonian to Villafranchian (MN7/8 to MN17), or about 10 my of sedimentary record. Of this set, only one locality, JV-1 is of Middle Miocene age. The rest of the localities contain taxa from zones MN11 to MN17.
Five new localities with rodent remains have been located in the Juan Vich ravine (Table 1). Their stratigraphic position can be correlated with that of localities with large mammals of La Portera and Venta del Moro. The age of the new mammal localities comprises the interval between MN6 and MN13 or MN14. In this paper we describe the rodent faunas from the new localities and hypothesize on the bio- and cronostratigraphic implications.

\section{Abbreviations}

JV2: Juan Vich 2; JV3: Juan Vich 3; JV6: Juan Vich 6; JVTS1: Juan Vich upper section 1; JVTLI1: Juan Vich lower lacustrine section 1; MN: European Neogene land mammal units; L, W: length and width, respectively. SCSIE (UV): Servei Central de Suport a la Investigació Experimental de la Universitat de València.

\section{Material and methods}

Five levels of marls and mudstones in lacustrine and palustrine deposits in the Juan Vich ravine have been sampled during the field campaign of 1996. The resulting fossils are provisionally kept in the Department of Geology of the University of Valencia (UV) with the field labels JV2-, JV3-, JV6-, JVTLI1- and JVTS1-. The nomenclature and measurement methods are that of Mein and Freudenthal (1971) (Cricetidae), Daams (1985) (Gliridae) and Cuenca (1985) (Sciuridae). Measurements (L x
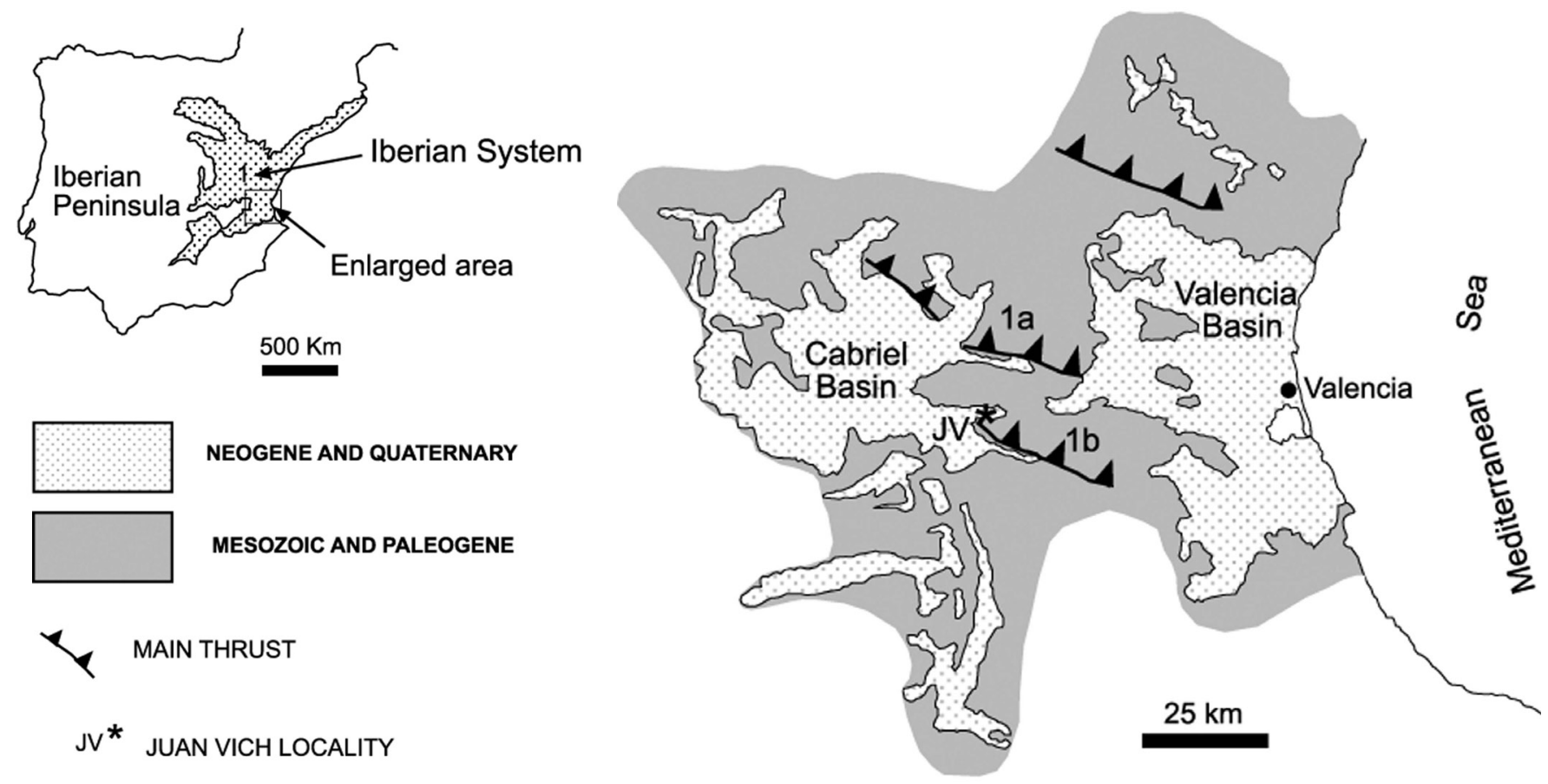

Fig. 1.- Geographic and geological setting of the Cabriel Basin, showing the location of the outcrops of the Juan Vich ravine (JV).

Fig. 1.- Esquema geográfico y geológico de la Cuenca del Cabriel, mostrando la localización de los afloramientos del barranco de Juan Vich (JV). 


\begin{tabular}{|c|c|c|c|c|c|}
\hline \multirow[t]{2}{*}{ Species } & \multicolumn{5}{|c|}{ Localities } \\
\hline & JV2 & JV3 & JV6 & JVTLI1 & JVTS1 \\
\hline Megacricetodon cf. crusafonti & $X(2)$ & $X(2)$ & $X(13)$ & & \\
\hline cf. Fahlbuschia or Democricetodon sp. & & $X(3)$ & & & \\
\hline Cricetodon sp. & & $X(1)$ & & & \\
\hline cf. Megacricetodon sp. & & & & $\mathrm{X}(1)$ & \\
\hline Heteroxerus sp. & $\mathrm{X}(1)$ & & & $X(1)$ & \\
\hline Heteroxerus grivensis & & $X(4)$ & & & \\
\hline Muscardinus cf. thaleri & $X(1)$ & & & & \\
\hline Occitanomys cf. alcalai & & & & & $X(1)$ \\
\hline
\end{tabular}

Table 1. Faunal lists of JV2, JV3, JV6, JVTLI1 and JVTS1. In brackets, the number of studied specimens.

Tabla 1. Listas faunísticas de JV2, JV3, JV6, JVTLI1 y JVTS1. Entre paréntesis, el número de especimenes estudiados.
W) are in tenths of millimetres and were taken on a Leica MZ75 binocular microscope, by means of displacement of a mechanical stage, connected to a Sony Magnescale measuring equipment.

\section{Geological setting}

The Tertiary deposits of the Juan Vich ravine are located in the eastern sector of the Cabriel Basin, also denominated Requena Basin or Venta del Moro Basin (Robles, 1970). This basin is the biggest Neogene depression in the structural domain named Castilian-Valencian Branch of the Iberian System (Fig. 1).

The Iberian System is an intraplate alpine orogen placed in the eastern sector of the Iberian Peninsula. The structural domain of the Castilian-Valencian Branch of the Iberian System is formed by a group NW-SE overthrusts facing towards the SW, that affect both the paleozoic basement and the Mesozoic cover (Fig. 1).

The Cabriel basin is an intrachain basin, developed between two of these thrusts: Buñol-Utiel thrust (Sierras of Cabrera, Tejo and Utiel; Fig. 1.1a) and Dosaguas thrust (Sierras of Ave, Martés and Rubial; Fig. 1.1b). Their deposits constitute a postorogenic sedimentary sequence, formed between early Miocene and late Pliocene, that cover Mesozoic and Paleogene deformed materials.

The Tertiary continental sediments of the Cabriel basin were deposited during the buildup of the Southern Branch (Castilian - Valencian tectonic domain) of the Iberian chain. They are constituted by two series separated by an angular uncorformity. The lower part is transitional with the marine Upper Cretaceous deposits. It is formed by Late Cretaceous (Villalba de la Sierra Formation) and Paleogene (up to Oligocene) deposits. Both were folded and fractured during the Alpine orogenesis. It contains a minimum of two megasequences with alluvial deposits, at the base, and lacustrine carbonates at the top, that have been related with the location of the Sieteaguas - Utiel thrust, in the northern margin of the Cabriel Basin (Santisteban and Ruiz-Sánchez, 2000) (Fig. 1.1a). No continental vertebrates have been found, except for remains of dinosaurs in the latest Cretaceous deposits (Vilas et al., 1982).

The Juan Vich sector belongs to the eastern margin of the Cabriel basin. The sedimentary record in this area consist of a 250 meters thick series, composed of lacustrine and alluvial deposits that overlap a substratum constituted by folded and fractured Jurassic and Cretaceous carbonates (Fig. 2). Until now, the lower deposits of this basin, located in the vicinities of Fuente Podrida spa, were considered of late Turolian age (Robles et al., 1991); however, the materials that crop out in Juan Vich contain a micrommal association that dates the beginning of the sedimentary history of this basin as Middle Miocene (Late Aragonian, MN6).

The stratigraphy by Robles (1970) and Aguirre et al. (1973) reveals that the infill of the Cabriel basin is formed by two sequences, each one composed of clastic alluvial and fluvial materials, at the base, and fresh-water lacustrine carbonates at the top. Assens et al. (1973a, 1973b), have proposed an alternative subdivision in stratigraphic units, with more than two cycles culminating each one in lacustrine carbonates, ranging from Early Miocene up to Late Pliocene.

The stratigraphic units that crop out in the Juan Vich section, are physically correlatable with the ones of Robles (1970), although they represent an age interval similar to the one proposed by Assens (1973a, 1973b).

\subsection{Stratigraphy and sedimentology}

The sedimentary record of this basin has been assigned to the Venta del Moro-Villatoya formation, composed of three members (Robles, 1970): Fuente Podrida Mb., Los Isidros $\mathrm{Mb}$. and Mirador Mb. The Fuente Podrida member is the lower one of the three and has a thickness of 60 meters. It is formed by gypsy marls at the base, and tufa limestones at the top. The Los Isidros member is a clastic unit. It is $200 \mathrm{~m}$ thick and it is formed by red or brown clays, sandstones and conglomerates. Locally, it presents intercalations of limestones, marls and gypsum. The Mirador member is the upper one of the three and has a thic- 


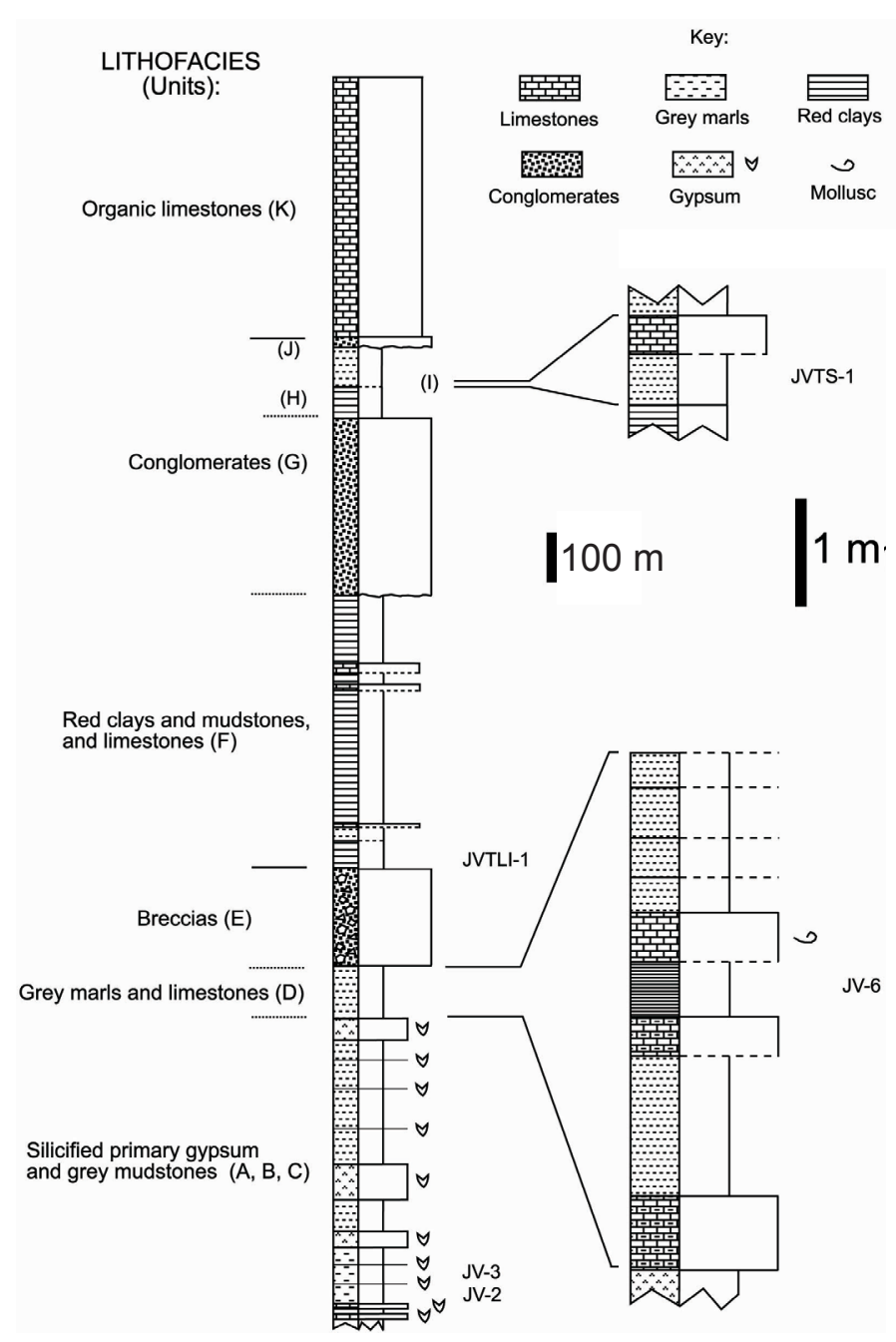

Fig. 2.- Stratigraphical position of the microvertebrate-bearing localities of the Juan Vich ravine (JV) (Units A, B, C, D, F and I).

Fig. 2.- Posición estratigráfica de los niveles con microvertebrados del barranco de Juan Vich (JV) (Unidades A, B, C, D, F e I).

kness of 30 meters. It is formed by grey tufa limestones that alternate with calcareous marls.

The studied sequence, has been measured throughout Juan Vich ravine, tributary of the Magro river (UTM base: 30S XJ 71484; UTM Top: 30S XJ 59800) This sequence (Fig. 2) is, from base to top:

A - 4 meters of intercalations of gray marls and white limestones with pseudomorphs of gypsum.

B - 4 meters of intercalations of red clays, gray marls and white limestones.

C - 52 meters of gray marls with thin beds of gypsum. It contains three layers, from 4 to 7 meters thick, formed by silica peudomorphs of primary free-growth selenites, and lenticular gypsum of interstitial growth. These layers present moulds of dessication cracks.

D - 10 meters of intercalations of gray marls with organic matter and white calcareous marls. It presents moulds of dessication craks.
E - 20 meters of breccias, with chaotic structure, formed by blocks and pebbles of Jurassic limestones and lower Cretaceous sandstones.

F - 55 metres of brown clays with three intercalations, of a thickness from 1 to 3 meters, of gray marls and limestones.

$\mathrm{G}$ - 36 meters of conglomerates with carbonate pebbles in a matrix of silicilastic sandstone, in amalgamated channeled bodies.

$\mathrm{H}-6$ metres of brown clays.

I - 8 meters of gray marls with an intercalation of palustrine limestones with root traces.

$\mathrm{J}$ - 2 meters of conglomerates composed of limestone pebbles.

K - 53 meters of gray limestones and marls.

The units F, G, H, I, and J belong to the Los Isidros member, while the upper limestones (unit K) represent the Mirador member.

From the sedimentological point of view the units A, B, $\mathrm{C}$ and $\mathrm{D}$ are palustrine and lacustrine deposits with alternations of saline and fresh-water stages. Unit $\mathrm{E}$ is a clastic deposit formed by gravitational mechanisms of mass transport of debris flow type. The units F, G, H, I, and J are deposits formed in an alluvial system. The carbonate unit $\mathrm{K}$ has been formed in a fresh-water lacustrine environment, dominated by organic production of sediment.

With the objective of characterizing the age of the materials of the Juan Vich sequence, we have sampled the palustrine and lacustrine deposits of the units A, B, C, D, $\mathrm{F}$ and I (Fig. 2). The sampling has allowed the location of five localities with micromammal remains: JV2, JV3, JV6, JVTLI1 and JVTS1.

\section{Systematic Palaeontology}

Order: Rodentia Bodwich, 1821

Family: Cricetidae Fischer de Waldheim, 1817

Genus: Megacricetodon Fahlbusch, 1964

Species Megacricetodon cf. crusafonti (Freudenthal, 1963) (Fig. 3/1-2)

Locality: Juan Vich 2 (JV2)

Material: 2 M1 (JV2-1, JV2-2)

\section{Description:}

MI: (17.15 x 11.36; 17.40 x 12.06): Anterocone slightly subdivided. In front of the anterocone a small platform is present. Anterolophule connected to the middle of the anterocone. One specimen has a short spur that points obliquely backwards towards the anterior wall of the paracone. Longitudinal and short ectoloph on the paracone. Mesoloph short or of medium length. In one specimen the ectoloph is connected to the mesoloph. Metalophule 
connected behind the hypocone. Posterosinus small.

\section{Discussion:}

The size of this material is bigger than in the populations of Megacricetodon primitivus and Megacricetodon collongensis from the lower and middle Aragonian, and very similar to that of, Megacricetodon crusafonti from the upper Aragonian of the Calatayud-Teruel basin (Daams and Freudenthal, 1988b) and Cazuma 1, a locality in the nearby basin of Quesa-Bicorp, where Megacricetodon crusafonti is also recorded (Ruiz-Sánchez et al., 2005). The morphology of Megacricetodon from JV2 is very similar to the populations of these last localities from the upper Aragonian. The presence of a slightly subdivided anterocone and of short and medium mesolophs and longitudinal ectolophs, connected or not to the mesoloph, is a common feature in Megacricetodon of this age (Daams and Freudenthal, 1988b).

Based on these features and until more material becomes available, we consider the assemblage from JV2 as belonging to a form related with $M$. crusafonti.

Species Megacricetodon cf. crusafonti (Freudenthal, 1963) (Fig. 3/5-6)

Locality: Juan Vich 3 (JV3)

Material: $1 \mathrm{~m} 3$ (JV3-2) and 1 M1 (JV3-1)

\section{Description:}

m3: (10.90 x 8.14): Anterosinusid absent. Protosinusid narrow. Sinusid transverse and well-developed. Mesolophid absent. Posterosinusid of medium size.

M1: (17.73 x 10.80): Anterocone slightly subdivided. In front of the anterocone a platform of medium size is present. Anterolophule very short and connected to the middle part of the anterocone. From the anterolophule a short spur points obliquely backwards towards the anterior wall of the paracone. Ectoloph on the paracone very short. Mesoloph short. Ectoloph and mesoloph are not connected. Metalophule simple and connected behind the hypocone. Posterosinus very small.

\section{Discussion:}

The presence of a slightly subdivided anterocone in the M1 from JV3 is a characteristic feature of the genus Megacricetodon (Daams and Freudenthal, 1988b). The M1 from JV3 is very similar in size and morphology to that of Megacricetodon cf. crusafonti from JV2. The anterior platform in front of the anterocone, the short spur on the anterolophule and similar development of ectolophs and mesolophs in M1 are features that match in both assemblages. The size values of $\mathrm{m} 3$ and M1 from JV3 match those of Megacricetodon species from the
Late Aragonian of the Calatayud-Teruel basin (Daams and Freudenthal, 1988b).

Species Megacricetodon cf. crusafonti (Fig. 3/13-18)

Locality: Juan Vich 6 (JV6)

Material: 3 m1 (JV6-1, JV6-2, JV6-9), 2 m2 (JV6-4, JV6-

5), 3 m3 (JV6-6, JV6-7, JV6-8), 2 M1 (JV6-10, JV6-

11), 1 M2 (JV6-13) and 2 M3 (JV6-14, JV6-15)

\section{Description:}

$m 1:(16.44 \times 10.62 ; 17.39 \times 10.39)$ : Anteroconid deeply split (2) or 8-shaped (1). Long labial spur of the anterolophulid in 2 out of 3 specimens. Mesolophid very short, nearly absent. Sinusid long and deep.

m2: ( x 10.31; x 9.71): Lingual anterolophid short. Mesolophid very short.

$m 3$ : (11.18 x 8.58; $11.04 \times$ 8.68): Lingual anterolophid short or of medium size. Metalophulid short or absent. Mesolophid and ectomesolophid absent. Hypolophulid short and transverse. Posterosinusid small.

M1: (16.86 x $10.44 ; 15.37 \times 10.52)$ : Anterocone deeply split without anterior platform or with anterior platform. Labial spur on the anterolophule absent. Ectoloph on the paracone short. Mesoloph short or of medium size and connected to the metacone. Ectoloph not connected to the mesoloph. Posterosinus small.

M2: (13.19 x 10.60): The protolophule is simple and points obliquely forward, connecting to the anterolophule in front of the protocone. Ectoloph on the paracone and mesoloph of medium size and not connected. Sinus transverse. Metalophule double, with the anterior branch interrupted. Posterosinus small and narrow.

M3: (8.65 x 9.58): Teeth of subrectangular shape. Protolophule transverse and complete, connected to the protocone. Sinus narrow. Neo-entoloph high and narrow or low and interrupted. Mesosinus open to the labial border. Centrocone strongly developed and connected to the hypocone. Axioloph interrupted (1) or well developed (1).

\section{Discussion:}

The size of Megacricetodon from JV6 matches the values of $M$. crusafonti from the Upper Aragonian and $M$. ibericus from the Upper Aragonian and Lower Vallesian of the Calatayud-Teruel basin (Daams and Freudenthal, 1988b). The M1 from JV6 is a bit smaller than the Vallesian form. The morphology of the $\mathrm{m} 1$ from JV6 is very different from $M$. ibericus, being the anteroconid of the $\mathrm{m} 1$ from JV6 not as deeply split as in M. ibericus. On the other hand, the presence of a double metalophule in the M2 is a very rare morphological feature in $M$. ibericus ( 1 out of 16 specimens in Nombrevilla) and 


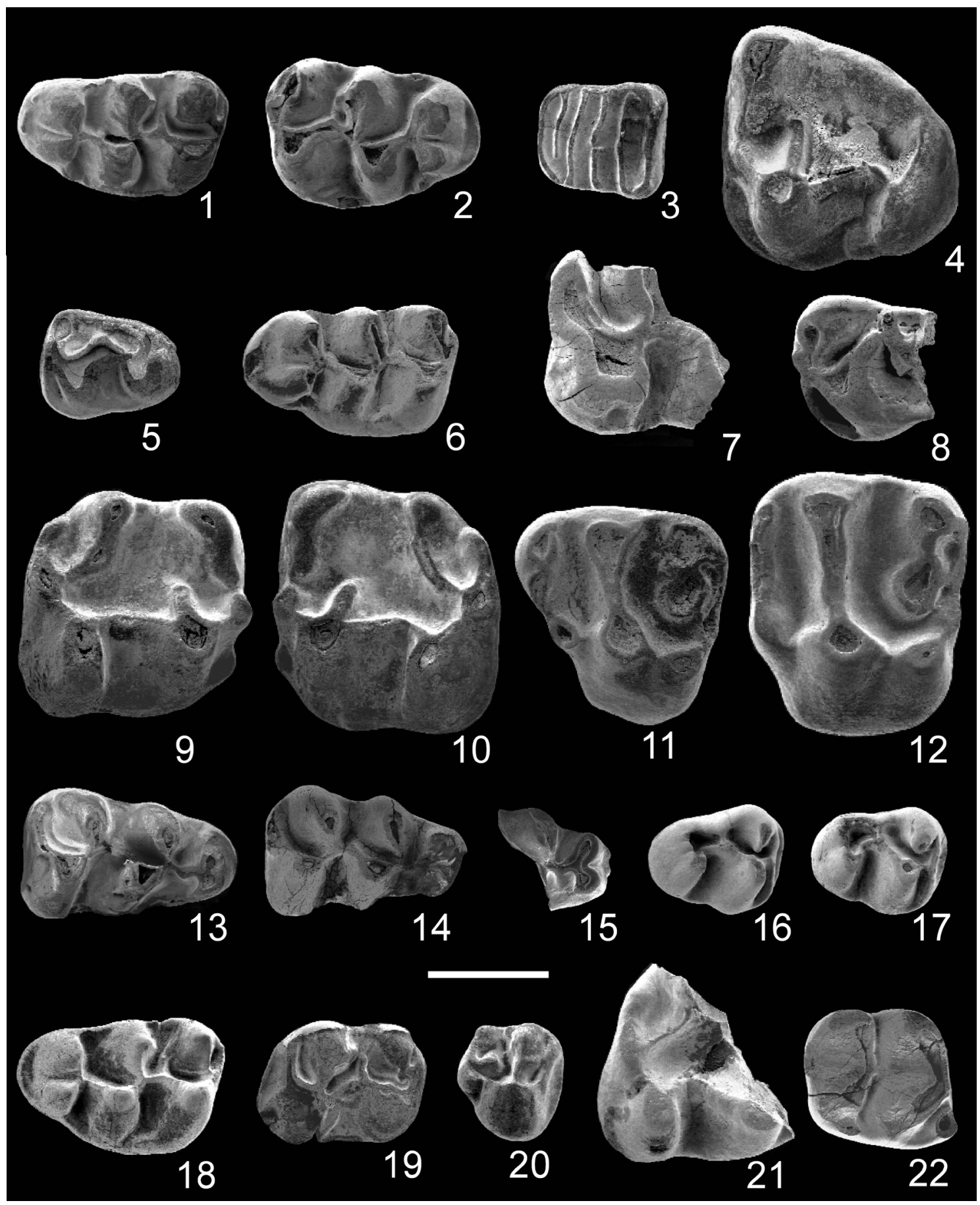

Fig. 3.- Rodent faunas from Juan Vich ravine (Cabriel Basin, Spain). Megacricetodon cf. crusafonti from JV2. 1, left M1, JV2-1; 2, right M1, JV22. Muscardinus cf. thaleri from JV2. 3, left m1, JV2-3. Heteroxerus sp. from JV2. 4, left m3, JV2-4. Megacricetodon cf. crusafonti from JV3. 5, left m3, JV3-2; 6, left M1, JV3-1. Cricetodon sp. from JV3. 7, right m2, JV3-4. cf. Fahlbuschia or Democricetodon sp. from JV3. 8, left m3, JV3-6. Heteroxerus grivensis from JV3. 9, right m1, JV3-8; 10, left m2, JV3-9; 11, right D4, JV3-10; 12, left M1,2, JV3-11. Megacricetodon cf. crusafonti from JV6. 13, right m1, JV6-2; 14, right m1, JV6-1; 15, right m1, JV6-9; 16, right m3, JV6-6; 17, right m3, JV6-7; 18, left M1, JV6-10; 19, left M2, JV6-13; 20, right M3, JV6-14. Heteroxerus sp. from JV6. 21, right m1,2, JVTLI1-2. Occitanomys cf. alcalai from JVTS1. 22, right $\mathrm{m} 2$, JVTS1-1. Scale $=1 \mathrm{~mm}$.

Fig. 3.- Roedores del barranco de Juan Vich (Cuenca del Cabriel, España). Megacricetodon cf. crusafonti de JV2. 1, M1 izquierdo, JV2-1; 2, M1 derecho, JV2-2. Muscardinus cf. thaleri de JV2. 3, m1 izquierdo, JV2-3. Heteroxerus sp. de JV2. 4, m3 izquierdo, JV2-4. Megacricetodon cf. crusafonti de JV3. 5, m3 izquierdo, JV3-2; 6, M1 izquierdo, JV3-1. Cricetodon sp. de JV3. 7, m2 derecho, JV3-4. cf. Fahlbuschia ou Democricetodon sp. de JV3. 8, m3 izquierdo, JV3-6. Heteroxerus grivensis de JV3. 9, m1 derecho, JV3-8; 10, m2 izquierdo, JV3-9; 11, D4 derecho, JV310; 12, M1,2 izquierdo, JV3-11. Megacricetodon cf. crusafonti de JV6. 13, m1 derecho, JV6-2; 14, m1 derecho, JV6-1; 15, m1 derecho, JV6-9; 16, m3 derecho, JV6-6; 17, m3 derecho, JV6-7; 18, M1 izquierdo, JV6-10; 19, M2 izquierdo, JV6-13; 20, M3 derecho, JV6-14. Heteroxerus sp. de JV6. 21, m1,2 derecho, JVTLI1-2. Occitanomys cf. alcalai de JVTS1. 22, m2 derecho, JVTS1-1. Escala=1mm. 
more frequent (39 out of 98 specimens in Solera) in $M$. crusafonti-ibericus from the localities of zone G3 (Daams and Freudenthal, 1988b). In JV6 the only M2 shows a double metalophule.

The presence of a long labial spur of the anterolophulid in 2 out of $3 \mathrm{~m} 1$ from JV6 is an uncommon feature in M. crusafonti, and it is not known in M. crusafontiibericus and M. ibericus. This character is not mentioned in M. crusafonti in Daams and Freudenthal (1988b), but Freudenthal (1963) reported a frequency of $20 \%$ in $M$. crusafonti from Manchones. This character is also present in some specimens of $M$. primitivus (5\% in Valtorres and $14 \%$ in Vargas 1A) (MN4 and lower part of MN5), $M$. collongensis (3\% in Casetón 1A and 10\% in Valdemoros $3 \mathrm{~B})(\mathrm{MN} 5)$ and $M$. debruijni (2\% in Pedregueras $2 \mathrm{C}$ and $17 \%$ in Pedregueras 2A) (upper part of MN9) from localities of the Calatayud-Teruel basin (Daams and Freudenthal, 1988b), but not in the same proportion as in JV6.

Outside the Iberian Peninsula this situation repeats. Whereas in $M$. aunayi from the French karstic locality of Blanquatère 1 (MN4-MN5) 21\% of the $\mathrm{m} 1$ have a labial spur on the anterolophulid (Lazzari and Aguilar, 2007), in M. aff. bavaricus from Estruguettes 5 (MN7-8) 2 out of 2 $\mathrm{m} 1$ have this character too (Aguilar et al., 1999; Fig. 6a). In M. bavaricus from Langenmoosen (MN5), Fahlbusch (1964) cites that most of the $\mathrm{m} 1$ also show this character. The size and dental pattern of the Megacricetodon from JV6 agree well with those of M. bavaricus from Langenmoosen and $M$. aff. bavaricus from Estruguettes 5.

Based on these features and until more material becomes available, we consider the assemblage from JV6 as belonging to a form related with $M$. crusafonti.

Species cf. Megacricetodon sp.

Locality: (JVTLI1)

Material: 1 M1 (JVTLI1-1)

\section{Description:}

M1: Worn tooth. Protosinus and sinus open to lingual border.

\section{Discussion:}

The tooth is strongly deteriorated, the enamel is partially lost. The general configuration of this specimen resembles Megacricetodon. In the anterior end, something like a split anterocone is present. Based on these facts, it is determined as cf. Megacricetodon sp.

Genus: Fahlbuschia Freudenthal, 1971

or Democricetodon Fahlbusch, 1964

Species Fahlbuschia or Democricetodon sp. (Fig. 3/8)

Locality: Juan Vich 3 (JV3)
Material: 1 m3 (JV3-6), 1 M1,2 (JV3-5) and 1 M3 (JV3-7)

\section{Description:}

m3: ( x 12.60): The posterior side is broken. Anterosinusid very small. Mesolophid absent. Hypolophulid very short.

M1,2: Only the posterolingual side is preserved. Sinus narrow and open to lingual border.

M3: Sinus small. Neo-entoloph high and complete. Posterosinus divided in two small portions by a short and longitudinal ridge.

\section{Discussion:}

The status of several cricetids from the Miocene (Fahlbuschia, Democricetodon, Pseudofahlbuschia and Renzimys) is still under discussion (Freudenthal 2006; Van der Meulen et al., 2004). The new classification suggested by Van der Meulen et al. (2004) was rejected by Freudenthal (2006). For the moment we use the classification of Freudenthal and Daams (1988).

The medium-sized $\mathrm{m} 3$ from JV3 matches the values of $F$. freudenthali and $F$. darocensis from the Aragonian type area, it is larger than Pseudofahlbuschia jordensi and somewhat smaller than $F$. crusafonti and any form of the genus Renzimys (Freudenthal and Daams, 1988). The presence of small and narrow sinuses in the upper molars, a neo-entoloph in the M3, a small anterosinusid and a short hypolophulid in the m3 from JV3 match the morphology of a form of Fahlbuschia or Democricetodon (Freudenthal and Daams, 1988). Based on these features, we determine this material as Fahlbuschia or Democricetodon sp.

Genus: Cricetodon Freudenthal, 1971

Species Cricetodon sp. (Fig. 3/7)

Locality: Juan Vich 3 (JV3)

Material: $1 \mathrm{~m} 1,2$ (JV3-4)

\section{Description:}

$m 1,2$ : The specimen is the posterior part of a $m 1,2$. Tooth moderately hypsodont with a size over $2 \mathrm{~mm}$ long. The enamel is wrinkled. Sinusid and posterosinusid relatively narrow.

\section{Discussion:}

The wrinkled enamel, big size of the specimen and moderate hypsodonty are clear features of the tribus Cricetodontini Schaub, 1925. The degree of hypsodonty is not as strong as in Hispanomys and Ruscinomys, the other Cricetodontini genera registered in the Miocene of SW Europe, and very similar to Cricetodon (Mein and Freudenthal, 1971). The material of this Cricetodontini from 
JV3 is very scarce, limited to a fragmentary specimen. Nevertheless, based on the size and the general morphology it is determined as Cricetodon sp.

Family: Gliridae Muirhead, 1819

Subfamily: Glirinae Thomas, 1897

Genus: Muscardinus Kaup, 1829

Species Muscardinus cf. thaleri de Bruijn, 1966 (Fig. 3/3)

Locality: Juan Vich 2 (JV2)

Material: $1 \mathrm{~m} 1$ (JV2-3)

\section{Description:}

$m$ 1: $(10.16 \times 9.59)$ : Tooth with six ridges. In the labial border, the first and third ridges are low connected. The second ridge is long and not connected to another ridge. The fourth ridge is divided into two parts. The fifth ridge is long too and it has three small tubercles. The fifth and sixth ridges are connected at the labial border.

\section{Discussion:}

Daams (1985; Fig. 7) distinguishes three morphotypes in the $\mathrm{m} 1$ of Muscardinus from the Aragonian. The first morphotype has seven ridges, while the second and third have six. In the third morphotype, the second ridge reaches the labial border, whereas in the second morphotype it does not. These morphological differences allow distinguishing the two Muscardinus species from the Aragonian. Whereas $M$. thaleri has an $\mathrm{m} 1$ with first and second morphotype, $M$. hispanicus only has $\mathrm{m} 1$ with the second ridge long and connected to first ridge. According to the scheme proposed, the material of Muscardinus from JV2 is determined as $M$. cf. thaleri.

Family: Sciuridae Gray, 1821

Genus: Heteroxerus Stehlin and Schaub, 1951

Species Heteroxerus sp. (Fig. 3/4)

Locality: Juan Vich 2 (JV2)

Material: $1 \mathrm{~m} 3$ (JV2-4)

\section{Description:}

m3: (19.84 x 18.61): Protoconid, metaconid, hypoconid, anteroconulid and hypoconulid well developed. Anterior wall vertical. Anterolophid low and complete, connected to the protoconid. Metalophid transverse and of medium size. Entolophid absent. Posterolophid continuous, developed from hypoconid to metaconid.

\section{Discussion:}

The shape is very similar to what is described for the genus Heteroxerus from the localities of Aragonian age of the Calatayud-Teruel basin (Cuenca, 1988). The size is bigger than those of $H$. rubricati, except those from localities Ramblar 7, Villafeliche 2A, Olmo Redondo 9, Valdemoros 1A, Valdemoros 3A, Regajo 2 and Vala1to $2 \mathrm{C}$. The size of the specimen from JV2 matches the maximum values of $H$. rubricati from these last localities. Apart from its size, it resembles Heteroxerus, in the absence of an entolophid in $\mathrm{m} 3$. Based on these facts, it is determined as Heteroxerus sp.

Species Heteroxerus grivensis (Forsyth Major, 1893) (Fig. 3/9-12)

Locality: Juan Vich 3 (JV3)

Material: 1 m1 (JV3-8), 1 m2 (JV3-9), 1 D4 (JV3-10) and

$1 \mathrm{M} 1,2$ (JV3-11)

\section{Description:}

$m 1:(19.48 \times 18.43)$ : Tooth of subquadrangular shape. Protoconid, metaconid, hypoconid, entoconid, anteroconulid and hypoconulid well developed. The metaconid is the highest cusp. Anterolophid short and connected to the protoconid. Metalophid short and attached to the metaconid base. Entolophid complete and connected to the hypoconulid. Posterolophid continuous and not connected to the entoconid.

$m 2$ : (19.14 x 20.45): Tooth of subrectangular shape. Protoconid, metaconid, hypoconid, entoconid, anteroconulid and hypoconulid well developed. The metaconid is the highest cusp. Anterolophid very small, as a fold in the anterior wall. Metalophid of medium size and obliquely directed backward. Entolophid complete and connected to the hypoconulid. Posterolophid continuous and not connected to the entoconid.

D4: (17.78 x 18.79): Tooth of subtriangular shape. The cusps are big and rounded and the ridges short. Four main cusps: protocone, paracone, metacone and hypocone and three conules: anteroconule, metaconule and hypoconule. The ridges are continuous and well developed.

M1,2: (18.14 x 21.51): Tooth of subrectangular shape. The cusps are big and rounded, and the ridges short. Four main cusps: protocone, paracone, metacone and hypocone and three conules: anteroconule, metaconule and hypoconule. The ridges are continuous and well developed. A short parastyle and a little mesostyl are present. Metacone and a large metaconule are connected by the metaloph. The metaconule is in close contact with the hypoconule. Posteroloph low, connecting hypoconule and metacone.

\section{Discussion:}

The shape and the size are within the range of $H$. grivensis from the localities of Aragonian age of the CalatayudTeruel basin (Cuenca, 1988). The size of teeth is almost always bigger than $H$. rubricati. It resembles $H$. grivensis 


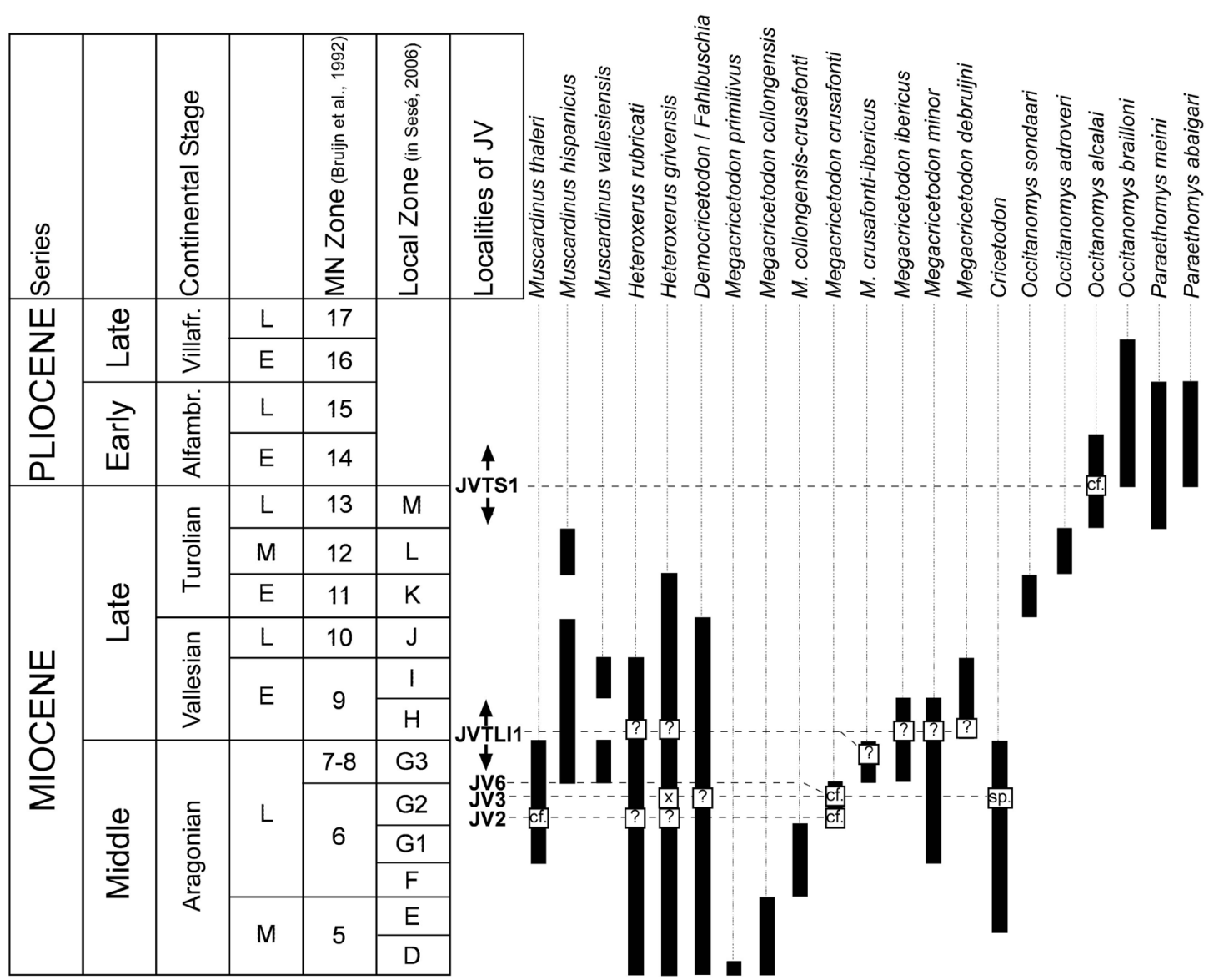

Fig. 4. Distribution chart of the rodents species studied in this paper and of other species of similar age. $\mathrm{X}=\mathrm{Con}-$ firmed presence of this taxon; ?= Possible species of the genus recorded in the locality.

Fig. 4. Cuadro de distribución de las especies de roedores estudiados en este trabajo y de otras especies de similar edad. $\mathrm{X}=$ Presencia confirmada del taxon; ?= Posible especie del género registrada en el yacimiento.

by the presence of a mesostyle and the close contact of metaloph (metaconule) and posteroloph in the upper molars. Therefore, it is determined as $H$. grivensis.

\section{Species Heteroxerus sp. (Fig. 3/19)}

Locality: Juan Vich lower lacustrine section 1 (JVTLI1)

Material: 1 m1,2 (JVTLI1-2)

\section{Description:}

$m 1,2$ : Anterior side of the tooth broken. A small part of an anterior cingulum is visible. Ectolophid short and curved. Entolophid long and connected to entoconid and hypoconulid. Posterolophid long and connected to the base of the entoconid.

\section{Discussion:}

The presence of a trace of an anterior cingulum, a long entolophid connected the entoconid and a hypoconulid are characteristic features of Heteroxerus (Cuenca, 1988). The scarce material does not allow a more detailed determination. Therefore it is classified as Heteroxerus sp.
Family: Muridae Illiger, 1811

Genus: Occitanomys Michaux, 1969

Species Occitanomys cf. alcalai Adrover, Mein and Moissenet, 1993 (Fig. 3/20)

Locality: Juan Vich upper sector (JVTS1)

Material: $1 \mathrm{~m} 2$ (JVTS1-1)

\section{Description:}

$m 2:(12.77 \times 11.16)$ : The posterior part of the tooth is narrower than the anterior part. Anterolabial cusp well developed, not connected to the protoconid. Between protoconid-metaconid and hypoconid-entoconid a small and low longitudinal spur is present. The labial cingulum is continuous, with a small $\mathrm{c} 1$ and a $\mathrm{c} 2$ attached to the labial wall of the protoconid. Hypoconid placed backward with respect to the entoconid. Posterior heel oval. There are two roots.

\section{Discussion:}

The tooth is brachyodont. There is a trace of a low longitudinal connection between the anterior and posterior cusp pair and a labial cingulum with a small $\mathrm{c} 1$. This 
morphology matches very well with those described in Occitanomys assemblages of Miocene age and resembles also Paraethomys (García-Alix, 2006). The size of the $\mathrm{m} 2$ from JVTS1 matches $O$. alcalai, and is clearly smaller than the rest of Occitanomys species and much smaller than any species of Paraethomys (García-Alix, 2006). Based on these facts and the scarce material, it is determined as Occitanomys cf. alcalai.

\section{Discussion}

The upper series of the Cabriel Basin is of Neogene age and represents the post-orogenic infill of the Cabriel basin. Until present it had been attributed to Upper Miocene and Pliocene (Robles, 1970). The lower part of the series of Juan Vich contains, at the base, lacustrine breccias associated to the synsedimentary activity of normal faults in the Mesozoic substratum. The materials of the upper part of this series are horizontal and without tectonic deformation.

A biostratigraphic chart, modified after Sesé (2006), is given in Figure 4. Biostratigraphically, the most important element in the first set of localities of Juan Vich ravine is the genus Megacricetodon. This genus usually is the most abundant taxon in the localities between MN4 and the lower part of MN9 (Daams and Freudenthal, 1988a-b; Daams et al., 1999). One form of this genus is present in the Juan Vich localities: Megacricetodon crusafonti (as M. cf. crusafonti). In the localities of the Calatayud-Teruel basin, M. crusafonti is characteristic of the Middle Miocene zone G2 (Daams and Freudenthal, 1988b). The rest of the taxa registered in the Juan Vich localities (Muscardinus, Heteroxerus, Cricetodon and Fahlbuschia or Democricetodon) are recorded in this time span too. The higher stratigraphic position of JVTLI1 with respect to JV2, JV3 and JV6 and the presence in the former locality of Megacricetodon sp. and Heteroxerus sp., allow dating this locality as Aragonian or Vallesian.

The locality JVTS1 contains the only murid recovered in Juan Vich. The first Muridae in Europe appear in the Lower Vallesian (MN9, Late Miocene) registers. From the Late Miocene onward and during a large part of the Pliocene murids are the dominant rodents in Europe (Freudenthal and Martín-Suárez, 1999). The specimen found in JVTS1 has been assigned to Occitanomys cf. alcalai. The stratigraphic range of $O$. alcalai is restricted to Late Miocene and Early Pliocene (Freudenthal and Martín-Suárez, 1999; García-Alix, 2006) (Fig. 4). Therefore we assign this locality to Late Turolian or Early Ruscinian (MN13 or MN14).

The microfauna found in the Juan Vich ravine indicates that the upper series of the Cabriel Basin dates from middle Miocene until the Pliocene. The lower part of the series of Juan Vich is Middle Miocene in age.

\section{Conclusions}

In the Juan Vich ravine the oldest sediments of the upper sequence of materials of the Cabriel basin crop out. This sequence represents the infill of one of the biggest post-orogenic basins in the southern branch of the Iberian system. The paleontological data provided by the new localities found in the Juan Vich ravine allow the first detailed dating of the stratigraphic units defined in the Juan Vich sector and that summarize the Tertiary deposits of the Cabriel basin.

New data on pre-Turolian faunas from the Cabriel basin are here presented. Five new localities of ages comprised between Middle Miocene to Late Miocene-Early Pliocene have been discovered in the Juan Vich ravine section. The oldest localities (JV2, JV3 and JV6) have an Aragonian age, the intermediate one (JVTLI1) is Aragonian or Vallesian and the youngest (JVTS1) is of Turolian or Alfambrian age.

The presence of the glirid Muscardinus, the cricetid Cricetodon and the murid Occitanomys represent the first records of these rodent genera in the Levantine sector of the Iberian Cordillera.

\section{Acknowledgements}

We thank to P. Gómez and E. Navarro (SCSIE, UV) for capable laboratory assistance, and Dr. Jorge Morales and an anonymous reviewer for their comments and criticism. Likewise, we thank the efficient work of editors, José López Gómez and Javier Martín Chivelet. This study was supported by the project CGL2008-06533-CO3-03/BTE.

\section{References}

Aguilar, J.P., Clauzon, G., Michaux, J. (1999): Nouveaux Cricétidés (Rodentia, Mammalia) dans le Miocène moyen de la region de Digne (Alpes de Haute Provence). Systématique, Biochronologie, Corrélations. Palaeontographica Abteilung A 253, 1-28.

Aguirre, E., Robles, F., Thaler, L., López-Martínez, N., Alberdi, M.T., Fuentes, C. (1973): Venta del Moro, nueva fauna finimiocena de moluscos y vertebrados. Estudios Geológicos 29, 569-578.

Alberdi, M.T., Arias, C., Bigazzi, G., Bonadonna, F.P., Leone, G., López, N., Michaux, J., Robles, F., Soria, D. (1982): Nuevo yacimiento de moluscos y vertebrados de la cuenca del Júcar (Albacete, España). Actes Colloque «Le Villafranchien méditerranéen», Lille, 1, 255-271.

Alberdi, M.T., Cerdeño, E., López-Martínez, N., Morales, J., Soria, D. (1997): La fauna Villafranquiense de El Rincón-1 (Albacete, Castilla-La Mancha). Estudios Geológicos, 1, 255-271. 
Assens-Caparrós, J., Ramírez del Pozo, J., García-Quintana, A., Hernando-Costa, S., Villena-Morales, J., Riba-Arderiu, O. (1973a): Hoja geológica num. 720 (Requena). Mapa geológico de España E. 1: 50.000. Segunda serie, I.G.M.E., Madrid.

Assens-Caparrós, J., Ramírez del Pozo, J., Riba-Arderiu, O., Villena-Morales, J., Reguant-Serra, S. (1973b): Hoja geológica num. 719 (Venta del Moro). Mapa geológico de España E. 1:50.000. Segunda serie, I.G.M.E., Madrid.

Benavent, J.V., Gascó, F., Ruiz-Sánchez, F.J., Montoya, P. (2008): Un Nuevo yacimiento con micromamíferos en el Mioceno Superior del área de Venta del Moro (Cuenca del Cabriel, Valencia). Stvdia Geologica Salmanticensia 8, 95105.

Bruijn, H., de, Daams, R., Daxner-Höck, G., Fahlbusch, V., Ginsburg, L., Mein, P., Morales, J., Heinzmann, E., Mayhew, D.W., Meulen, A.J. van der, Schmidt-kittler, N., Telles-Antunes, M. (1992): Report of the RCMNS working group on fossil mammals, Reisensburg 1990. Newsletters on Stratigraphy 26, 65-118.

Cuenca, G. (1985): Los roedores (Mammalia) del Mioceno inferior de Autol (La Rioja). Ediciones del Instituto de Estudios Riojanos-Ciencias de la Tierra, Logroño: 96 p.

Cuenca, G. (1988): Revisión de los Sciuridae del Aragoniense y del Rambliense en la fosa de Calatayud - Montalbán. Scripta Geologica, 87: 1-116.

Daams, R. (1985): Glirinae (Gliridae, Rodentia) from the type area of the Aragonian and adjacent areas (provinces of Teruel and Zaragoza, Spain). Scripta Geologica 77, 1-20.

Daams, R., Freudenthal, M. (1988a): Synopsis of the DutchSpanish collaboration program in the Aragonian type area, 1975-1986. In: M. Freudenthal (ed.), Biostratigraphy and paleoecology of the Neogene micromammalian faunas from the Calatayud-Teruel Basin (Spain). Scripta Geologica, special issue 1, Leiden: 3-18.

Daams, R., Freudenthal, M. (1988b): Cricetidae (Rodentia) from the type-Aragonian, the genus Megacricetodon. In: M. Freudenthal (ed.), Biostratigraphy and paleoecology of the Neogene micromammalian faunas from the Calatayud-Teruel Basin (Spain). Scripta Geologica, special issue 1, Leiden: 39-132.

Daams, R., Meulen, A.J. van der, Álvarez Sierra, M.A., Peláez-Campomanes, P., Krijgsman, W. (1999): Aragonian stratigraphy reconsidered, and a re-evaluation of the middle Miocene mammal biochronology in Europe. Earth and Planetary Science Letters 165, 287-294. doi:10.1016/j. eps1.2006.01.034.

Fahlbusch, V. (1964): Die Cricetiden (Mammalia) der Oberen Süsswassermolasse Bayerns. Abhandlungen der Bayerische Akademie der Wissenschaften 118, 1-136

Freudenthal, M. (1963): Entwicklungsstufen der miozänen Cricetodontinae (Mammalia, Rodentia) Mittelspaniens und ihre stratigrafische Bedeutung. Beaufortia 119, 51-157.

Freudenthal, M. (2006): The status of Democricetodon, Fahlbuschia, Pseudofahlbuschia and Renzimys (Cricetidae, Mammalia). A reply to Van der Meulen et al., (2004). Geobios 39, 43-55. doi:10.1016/j.geobios.2004.08.005.
Freudenthal, M., Daams, R. (1988): Cricetidae (Rodentia) from the type-Aragonian; the genera Democricetodon, Fahlbuschia, Pseudofahlbuschia nov. gen., and Renzimys. In: M. Freudenthal (ed.), Biostratigraphy and paleoecology of the Neogene micromammalian faunas from the CalatayudTeruel Basin (Spain). Scripta Geologica, special issue 1, Leiden: 133-252.

Freudenthal M., Martín-Suárez, E. (1999): Family Muridae. In: G.E. Rössner and K. Heissig (eds.), Land Mammals from Europe, Verlag Dr. Friedrich Pfeil, München: 401-409.

Freudenthal, M., Mein, P., Martín-Suárez, E. (1998): Revision of Late Miocene and Pliocene Cricetinae (Rodentia, Mammalia) from Spain and France. Treballs del Museu de Geologia de Barcelona 7, 11-93.

García-Alix, A. (2006): Bioestratigrafía de los depósitos continentales de la transición Mio-Plioceno de la Cuenca de Granada. Tesis Doctoral. Universidad de Granada: 386 p.

Lacomba, J.I., Morales, J., Robles, F., Santisteban, C., Alberdi, M.T. (1986): Sedimentología y paleontología del yacimiento finimioceno de La Portera (Valencia). Estudios Geológicos 42, 167-180.

Lazzari, V., Aguilar, J.P. 2007. Les Megacricetodon du gisement karstique miocène moyen de Blanquatère 1 (Pyrénées-Orientales, Sud de la France): nouvelles espèces, implications biochronologiques et phylogéniques. Geobios 40, 91-111. doi:10.1016/j.geobios.2005.07.004.

López-Martínez, N. (1989): Revisión sistemática y biostratigráfica de los Lagomorpha (Mammalia) del Terciario y Cuaternario de España. Memorias del Museo de Paleontología de la Universidad de Zaragoza 3, 1-350.

Mansino, S., Montoya, P., Luque, L., Ruiz-Sánchez, F.J., Benavent, J.V. (2009): La Bullana 2B: faunas de micromamíferos del Plioceno en el área de Venta del Moro (Valencia, España). Resúmenes XXV Jornadas de la Sociedad Española de Paleontología, Ronda: p. 204-206.

Martín-Suárez, E., Oms, O., Freudenthal, M., Agustí, J., Parés, J.M. (1998): Continental Mio-Pliocene transition in the Granada Basin. Lethaia 31, 161-166. doi: 10.1111/j.15023931.1998.tb00503.x

Martín-Suárez, E., Freudenthal, M., Krijgsman, W., RutgerFortuin, A. (2000): On the age of the continental deposits of the Zorreras Member (Sorbas Basin, SE Spain). Geobios 33 (4), 505-512. doi:10.1016/S0016-6995(00)80084-4.

Mein, P., Freudenthal, M. (1971): Les Cricetidae (Mammalia, Rodentia) du Néogène Moyen de Vieux-Collonges. Partie 1: Le genre Cricetodon Lartet, 1851. Scripta Geologica 5, 1-51.

Mein, P., Moissenet, E., Truc, G. (1978): Les formations continentales du Néogène Supérieur des Vallées du Júcar et du Cabriel au NE d'Albacete (Espagne). Bioestratigraphie et Environment. Documents des Laboratoires de Géologie de la Faculté des Sciences de Lyon 72, 99-147.

Mein, P., Martín-Suárez, E. (1993): Galerix iberica sp. nov. (Erinaceidae, Insectivora, Mammalia) from the Late Miocene and Early Pliocene of the Iberian Peninsula. Geobios 26, 723-730. doi:10.1016/S0016-6995(93)80055-V.

Montoya, P., Morales, J., Robles, F., Abella, J., Benavent, J.V., Marín, Ma.D., Ruiz-Sánchez, F.J. (2006): Las nuevas exca- 
vaciones (1995-2006) en el yacimiento del Mioceno final de Venta del moro, Valencia. Estudios Geológicos 62, 313-326.

Morales, J. (1984): Venta del Moro: su macrofauna de mamiferos y biostratigrafía continental del Mioceno terminal mediterráneo. Editorial Universidad Complutense, Madrid: $340 \mathrm{p}$.

Opdyke, N., Mein, P., Moissenet, E., Pérez-González, A., Lindsay, E., Petko, M. (1990): The magnetic stratigraphy of the late Miocene sediments of the Cabriel Basin, Spain. In: E.H. Lindsay, V. Fahlbusch and P. Mein. (eds.), European Neogene Mammal Chronology, Plenum Press, New York: 507514.

Opdyke, N., Mein, P., Lindsay, E., Pérez-González, A., Moissenet, E., Norton, V.L. (1997): Continental deposits, magnetostratigraphy and vertebrate paleontology, late Neogene of Eastern Spain. Palaeogeography, Palaeoclimatology, Palaeoecology 133, 129-148. doi:10.1016/S00310182(97)00080-1.

Robles, F. (1970): Estudio estratigráfico y paleontológico del Neógeno del río Júcar, Tesis Doctoral. Universitat de València: $275 \mathrm{p}$.

Robles, F., Torrens, J., Aguirre, E., Ordóñez, S., Calvo, J.P., Santos-García, J. (1974): Levante. In: E. Aguirre and J. Morales (eds.), Coloquio Internacional sobre bioestratigrafía continental del Neógeno superior y Cuaternario, Editorial CSIC, Madrid: 85-135.
Robles, F., Belinchón, M., García-Flor, J., Morales, J. (1991): El neógeno continental de Buñol, y del valle del río Cabriel. Revista Española de Paleontología No extraordinario, 205215.

Ruiz-Sánchez, F. J., Santisteban, C., Lacomba, J.I. (1994): Edad de los depósitos inferiores de la Cuenca del Cabriel en la localidad Fuen Vich-1. Resúmenes III Congreso del Grupo Español del Terciario, Jaca: p. 197-200.

Ruiz-Sánchez, F.J., Santisteban, C., Lacomba-Andueza, J.I. (2005): Cazuma 1, nueva localidad de micromamíferos (Mammalia, Rodentia) del Aragoniense Superior en la cuenca de Quesa-Bicorp (Prov. Valencia). Revista Española de Paleontología 10, 101-109.

Santisteban, C., Ruiz-Sánchez, F.J. (2000): Evolución del registro sedimentario de la Cuenca del Río Magro (Provincia de Valencia). Geotemas 1(2), 217-219.

Sesé, C. (2006): Los roedores y lagomorfos del Neógeno de España. Estudios Geológicos 62(1), 429-480.

Van der Meulen, A.J., Peláez-Campomanes, P., Daams, R. (2004): Revision of medium-sized Cricetidae from the Miocene of the Daroca-Villafeliche area in the Calatayud-Teruel basin (Zaragoza, Spain). Coloquios de Paleontología Vol. Extra 1, 385-441.

Vilas, L., Mas, J.R., García, A., Arias, C., Alonso, A., Meléndez, N., Rincón, R. (1982): 8. Ibérica Suroccidenta. In: El Cretácico de España, Editorial Universidad Complutense, Madrid: 457-513. 